Arab Univ. J. Agric. Sci., Ain Shams Univ., Cairo, 14(1), 457-474, 2006

\title{
SUBCHRONIC TOXICITY OF MANCOZEB FUNGICIDE ON MALE WISTAR RATS: ULTRASTRUCTURAL ANALYSIS OF LIVER AND KIDNEY
}

\section{[31]}

\author{
Madiha M. Talha' ${ }^{1}$;.M. Kenawy ${ }^{1}$ and Salwa M. Abd-Allah ${ }^{1}$
}

\begin{abstract}
Dithiocarbamate mancozeb, an organometallic fungicide, was administered orally to male Wistar rats in two forms, pure technical $85 \%$ and formulated $80 \% \mathrm{WP}$, at sublethal doses of 125,250 and $500 \mathrm{mg} / \mathrm{kg}$ b.w. for 28 days. Clinical chemical endpoints were measured after 2, 3, and 4 weeks of treatment initiation. Data disclosed that both compound formulations affected significantly serum enzyme activities particularly liver enzymes in a dose and time-dependent manner, compared with control. Such changes were accompanied with significant alterations in other parameters like; total protein, albumin, glucose, total lipids, triglycerides, cholestrol, urea, and creatinine. Furthermore, histological examination of liver and kidney showed several histopathogenic ubnormalities in the examined tissues of rats exposed to mancozeb either technical or formulated.
\end{abstract}

Keywords: Fungicides, Formulations, Toxicity, Liver, Kidney

\section{INTRODUCTION}

The increasing use of pesticides all over the world makes it necessary to reveal the toxic risk in populations of nontarget organisms (Hassal, 1990). Among these, Maneb, Zineb, Ziram, Mancozeb and Propineb are organometallic dithiocarbamate fungicides. Nowadays, mancozeb evokes controversial arguments in Egypt concerning its environmental hazardous effects and recently a ministerial decree (\#719/2005) has banned mancozeb marketing. It has previously been reported that dithiocarbamates form metabolites called isothiocyanates which may disrupt protein synthesis and metabolism, by inactivating - $\mathrm{SH}$ groups in amino acids, proteins and enzymes (Ware, 1983; Lukens, 1971). Ethylenethiourea, also one of the metabolites of ethylenebisdithiocarbamate fungicides, has been reported to be carcinogenic, teratogenic and mutagenic in experimental animals (Teramoto et al 1975; Larsson et al 1976).

1- Mammalian Toxicology Dept., Central Agricultural Pesticides Laboratory, ARC, Alexandria, Egypt

(Received September 14, 2005)

(Accepted November 19, 2005) 
Mancozeb (Mn- and Zn-containing dithiocarbamate) a commonly used fungicide, have been shown to induce tumors in mouse skin and rats (Subramoniam et al 1991). Mancozeb was also found to cause an increase in glutathione transferase activity in the liver of new-born, weanling and adult rats (Trivedi et al 1993) and was found to alter the hematological parameters of aquatic organisms (rainbow trout) at sublethal concentrations for 3 weeks (Atamanalp and Yanik, 2003).

Moreover, agricultural exposure to the organomanganese fungicides is said to induce an extra-pyramidal syndrome resembling Parkinsonism (Meco et al 1994). Soleo et al (1996) suggested that ethylene-bis-dithiocarbamates rather than Mn may be primarily responsible for the cytotoxicity of organomanganese fungicides on neuronal systems.

Few studies have been carried out on the mechanisms of organometalic fungicide action or on the fate of fungicides in target organisms. However, many studies have been reported on the effects of heavy metals alone in a variety of organisms (Kendrick et al 1992). Such metals may also affect many key biological systems such as oxidative phosphorylation, membrane permeability and protein synthesis. Increases in trace metal levels in cells may result in chelation with biological components, particularly with enzymes, again causing cellular damage (Lukens, 1971; Ware, 1983). The current study aims to evaluate and compare the histopathological/biochemical effects of the organometallic fungicide mancozeb in two tested forms on different organs of male rats particularly liver and kidney.

\section{MATERIAL AND METHODS}

Chemicals: Mancozeb (manganese ethylene bis-dithiocarbamate; polymeric) was provided from EL-HELB Pesticides\& Chemicals Co. (New Damietta, Egypt). The technical grade was $85 \%$ technical, while the formulated one was Anadol Gold (80\% WP). Both physical and chemical characteristics of the tested formulation were firstly examined and confirmed by GC-FPD compared with the technical grade.

Animals and treatment: Male adult Wistar rats (70-80 days of age, $150 \pm 10$ gm body weight) were housed and allowed to acclimatize for one week before initiation of treatment, feeding on a commercial diet and water ad libitum. Animals were divided into four groups for each of the tested compounds. Each group is composed of 10 rats and the four groups were treated with $0,125,250$ and $500 \mathrm{mg} / \mathrm{kg} \mathrm{b.w}$. of technical and formulated mancozeb; respectively daily for 28 days. The doses administered represent a certain percentage of the oral $\mathrm{LD}_{50}$ of the tested compounds. All studies were conducted in accordance with Good Laboratory Practice Standards and Oral Toxicity Guidelines for Pesticide Testing (Organization for Economic Cooperation and Development, OECD, 1995).

Sample preparation: Blood was collected by orbital sinus technique (Schalm, 1986) from both treated and control rats at time intervals of 14, 21 and 28 days. Serum was separated via centrifugation at $3500 \mathrm{rpm}$ for 10 minutes and kept frozen at $-20^{\circ} \mathrm{C}$ for subsequent analysis. At the end of the study, all animals were killed, 
examined grossly and liver and kidney were removed and prepared for histological examination.

Biochemical measurements: Several toxicity biomarkers measuring liver and kidney functions were assayed including alanine and aspartate aminotransferases; ALT and AST, alkaline phosphatase; ALP, and acetyl cholinesterase activities; AChE, total protein, albumin, glucose, urea, creatinine. Furthermore, total lipids, cholesterol and triglyceride concentration were measured. All the examinations were performed using commercial diagnostic kits, Stanbio Co., Spain).

Histopathological examination: At the end of experimental period (28 days), animals were sacrificed (OECD, 1995). Liver and kidey were freshly dissected and placed in 10\% formaldehyde and dehydrated in 70-100\% ethanol series. They were then placed in paraffin baths at $58^{\circ} \mathrm{C}$ for paraffin inclusion. Sections of 4-6 $\mu \mathrm{m}$ were prepared from paraffin blocks using a rotary microtome. These sections were then stained with Hematoxylin-Eosin (H-E) and photographed using photomicroscope (Carleton et al 1967)

Statistical analysis: Data were expressed as mean \pm S.E. and significant differences of values were analyzed using students T-test (Snedecor and Cochran, 1989).

\section{RESULTS AND DISCUSSION}

The potential biochemical end-points describing the dose-response relationship and concurrent histopathological impairments exerted in animals under mancozeb intoxication (technical or formulated) are highlightening in the following represented data obtained under the experimental conditions.

As regards to the toxic effects on liver as an organ with several complex activities, liver injury due to pesticide intoxication results in release of liver enzymes (AST, ALT, ALP) into blood stream as index of cellular degeneration and lysosomal activity linked to pesticide elimination (Verplanke et al 2000). Accordingly, data in Table (1) showed that technical mancozeb caused a significant elevation in ALT activity at all the tested dose regimens during the whole experimental period. While, AST activity was significantly decreased at 125 and $250 \mathrm{mg} / \mathrm{kg}$ throughout the test period, but the higher dose $(500 \mathrm{mg} / \mathrm{kg})$ caused elevation in AST activity. Furthermore, all doses caused significant increase in ALP activity after 28 days of treatment. The lower dose inhibited ALP activity while the higher stimulated the enzyme activity after 14 and 21 days of treatment; respectively. Comparatively, ALT and ALP activities were decreased significantly in a dose-dependent manner after treatment with Anadol Gold at all the tested doses and allover the experimental period while, AST activity was significantly increased also in a dose-dependent manner after all time intervals (Table, 2).

Since mancozeb is an organometalic fungicide, the released metals (Mn and Zn) may affect many key biological systems such as oxidative phosphorylation, membrane permeability and protein synthesis. Increases in trace metal levels in cells may result in chelation with biological components, particularly with enzymes, again causing cellular damage (Lukens, 1971; Ware, 1983). 
The obtained data are matching with the previous literatures studying the toxicity of mancozeb. Kackar et al (1997\& 1999) reported that mancozeb has produced significant enzymatic changes in the activities of AST, ALT and ALP after oral administration of 500, 1000, 1500 $\mathrm{mg} / \mathrm{kg}$ to male rats for $30,90,180$ and 360 days. Also, Szepvolgyi et al (1989) showed that Dithan M-45 (80\% mancozeb) decreased the detoxication capacity of the rat liver at 253 and $379 \mathrm{mg} / \mathrm{kg}$ for 12 week. Furthermore, the present findings run parellel in part with Hashizame et al (1992) who stated that a significant increase in each of serum AST and ALP after administration of bithional sulfoxid and thiobendazole fungicides to rats and mice.

Interstingly, AChE activity shown in Tables (1) and (2) indicates that both forms of mancozeb caused significant increase in AChE activity.The technical one caused significant increase of the enzyme activity in a dose and timedependent manner whereas the intermediate dose of the formulated mancozeb $(250 \mathrm{mg} / \mathrm{kg})$ caused significant elevation after all tested time intervals and the higher dose $(500 \mathrm{mg} / \mathrm{kg})$ caused a lesser degree of enzymatic activation. These data agree with Kackar et al (1999) who stated that mancozeb altered significantly the activity of rat $\mathrm{AChE}$ throughout the study period (360 days) in a dose dependent manner. On the other hand, Siddiqui et al (1990) showed that $\mathrm{AChE}$ activity was unaffected in rats orally administrated with mancozeb at $250 \mathrm{mg} / \mathrm{kg}$ for 30 days. Also, El-Halwagy et al (2003) reported that administration of sulfur containing fungicide (Panadol 8\%) at $1 / 5$ or $1 / 10 \mathrm{LD}_{50}$ for 30 days showed non-significant changes in serum AChE activity throughout the experimental period.

Leakage of enzymes into the blood stream was accompanied with disturbance in protein content due to affection of membrane permability and protein biosynthesis. The current data showed an increase in serum total protein and albumin particularly after 28 day of treatment with the technical mancozeb but during the other tested periods, the lower dose caused significant elevation in protein content and albumin while the higher dose exhibited a decreasing trend (Table, 1). On the other hand, treatment with Anadol Gold decreased the total protein content and albumin non-significantly during the whole experimental period, compared with the corresonding control.

Similarly, Dacosto et al (1994) recorded that rabbits serum total protein and albumin levels were apparently altered by triphenytin acetate fungicide treatment at 15, 75 and $150 \mathrm{ppm}$ for 70 days. Also, Mahadevaswami et al (2000) showed that the level of total protein was elevated in the liver of rats treated with 700 and $800 \mathrm{mg} / \mathrm{kg} \mathrm{b.w}$. /day of mancozeb for 15 consecutive days. Also, rats treated by $1 / 10 \mathrm{LD}_{50}$ of Panadol $8 \%$ sc fungicide showed a significant decrease in serum total protein and albumin concentration (El-Halwagy et al 2003).

Blood glucose concentration was significantly increased after treatment with technical mancozeb for 21 days, while, it was noticed that all the tested concentrations showed a decreasing pattern of glucose level in a dose-dependent manner after 14 and 28 days of exposure. Treatment with Anadol Gold caused significant increase in blood glucose level after all times of treatment of all dose regimens in a dose and time-dependent manner 
Arab Univ. J. Agric. Sci., 14(1), 2006 
(Tables, 1, 2). Alteration of blood sugar level was previously documented after exposure to similar fungicides (Rizk Alla et al 2004).

Furthermore, lipid profile was found to be affected due to mancozeb intoxication reflecting disturbance in lipid metabolism possibly due to peroxidation. Abnormal serum lipids levels also may be secondary to a number of liver disease, biliary cirrhosis and nephritic syndrome (Kelly, 1993). Data represented in Table (3) exhibited that technical mancozeb has led to significant increase in total lipids at the doses 125 and $500 \mathrm{mg} / \mathrm{kg}$ only after 21 day and at $250 \mathrm{mg} / \mathrm{kg}$ after 14 days of exposure while the general trend was decreasing in the level of total lipids throughout the whole exposure period. Furthermore, level of triglycerides was fluctuating, it was decreased significantly after treatment for 14 and 28 days but increased after 21 day of treatment. Serum cholesterol level was significantly increased after all doses regimens at all different times of exposure.

Some pesticides including fungicides are already known to disrupt lipid metabolism (Timbrell, 1991). Abu El-Zahab et al (1991) have indicated a link between serum cholesterol levels and the metabolism of certain metals. A high degree of fatty change occurred in most organs of the females administered with $400 \mathrm{ppm}$ propineb fungicide where $\mathrm{Zn}$ is known to affect lipid peroxidation in biological membranes (Prasadad, 1979). Terada $\boldsymbol{e t}$ al (1998) reported a significant increase in total lipids, cholesterol and triglycerides in rats treated with Mepanipyrin fungicide.

On the other hand, formulated mancozeb caused a significant decrease in levels of total lipids and total cholesterol with all doses after different time intervals compared with the control. Also, triglycerides showed the same decreasing pattern except at the doses of 250 and 500 $\mathrm{mg} / \mathrm{kg}$ after 14 day of exposure.

The obtained results agree with that reported by Kackar et al (1997) who stated that serum cholesterol increased in rats treated with $500 \mathrm{mg} / \mathrm{kg}$ mancozeb for 90 days. Also Szepvolgyi et al (1989) reported that serum cholesterol level was increased significantly in rats given Dithane M-45 (80\% mancozeb) at 75 $\mathrm{mg} / \mathrm{kg}$ for 12 week. It was also found that doses of 113,169 and $253 \mathrm{mg} / \mathrm{kg}$ caused elevation of triglyceride content. Rats treated with 600,700 and $800 \mathrm{mg} / \mathrm{kg} /$ day mancozeb showed a signifigant decrease in the level of total lipids, phospholipid and neutral lipid in liver (Mahadevaswami et al 2000) but Baligar and Kaliwal, (2001) reported that exposure to $500 \mathrm{mg} / \mathrm{kg} /$ day mancozeb for 30 days caused a significant increase in total lipids in the liver of treated rats.

Exposure to fungicides-containing metals results in metal accumulation in certain tissues and organs of the exposed organisms. It is also known that metals may cause extensive damage to the organs in which they accumulate causing biochemical and histopathological changes (Goyer, 1986; Wlostowski, 1992).

Histopathological examination of the liver disclosed that both of technical mancozeb and Anadol Gold caused an obviously histopathological alterations. Both doses of technical mancozeb (500, $125 \mathrm{mg} / \mathrm{Kg}$ ) caused hyperplasia of Von Kupffer cells accompanied with dilation and congestion of portal vein with red blood cells and the sinusoidal spaces were engarged with large focal area of 
inflammatory cells (Fig. 2 a,b). Also severe necrosis and hemosiderin pigments were seen in case of treatment with the lower dose (Fig. 3 a,b). Necrosis may be due either to severe degeneration or to metabolic disturbance and inhibition of protein synthesis in the liver cells or to direct effect of haemorrhage. Similarly, formulated mancozeb exhibited a similar pattern accompanied with hydropic and fatty degeneration of hepatocytes and absence of the regular arrangement of hepatic strands and architecture (Figs. 4 a,b and 5 a,b).

These results agree with Belpoggi $\boldsymbol{e t}$ al (2002) who reported that mancozeb at the concentrations of $10,100,500$ and $1000 \mathrm{ppm}$ fed for 104 weeks caused, an increase in hepatocarcinomas in rat liver. On the other hand, Jeffrey et al (2000) showed that there is no histological alterations in the liver of male rats treated with metiram (EBDC) fungicide at 84 $\mathrm{mg} / \mathrm{kg} /$ day for 13 week.

Concerning renal involvement upon exposure to mancozeb, determination of blood urea and creatinine levels indicated a worsening of kidney function. Table (4) showed that technical mancozeb caused a significant decrease in blood urea level particularly after 21 and 28 days of exposure accompanied with a decreasing pattern in creatinine concentration except at the higher dose which caused a significant elevtion in creatinine concentration after 14 day of treatment. In case of treatment with Anadol Gold (80\% WP), a significant increase in both urea and creatinine concentrations at all doses after 28 days of treatment was recorded. The highest concentrations of urea and creatinine were recorded after 14 and 28 days of exposure; respectively. Elevation in serum creatinine may be due to increase in the protein catabolic rate.
A comparative study of Dacosto et al (1994) reported that triphenyltine acetate fungicide increased blood urea nitrogen levels in rabbit treated by 15,75 and 150 ppm for 70 days and suggesting a possible renal involvement. While, Jeffrey et al (2000) reported that rats fed on diet containing metiram (EBDC) fungicide at $960 \mathrm{ppm}$ for 13 weeks showed a significant decrease in blood urea concentration. Hasegawa et al (1993) showed that propineb causes cancer in the thyroid, kidney and urinary bladder of rats.

Similar to the liver tissues, kidney tissues have been seriously affected by mancozeb intoxication and such impairments become more prominent with the higher dose of the fungicide rather than the lower one. The type of renal damage observed under the influence of technical mancozeb included deposition of hyaline casts in the renal tubular vacuoles (Fig. 6) and congestion of blood vessels between the convoluted tubules (Fig. 7). Compatatively, formulated mancozeb caused greater changes than the technical one summarizing in appearance of focal congestion in glomeruli, interstatial haemorrhage and inflammatroy cells between the renal tubules in the corticomedullary junction (Fig. 8 a,b). Such haemorrhage may be due to an increase of intravascular tension or venous congestion or due to a depolarization of mucopolysaccharides which permits blood to leave the vascular system. The lower dose of formulated mancozeb caused similar changes in addition to dilation of collecting tubules accompanied with marked glomerular degeneration and lysis (Fig. 9 a,b).

Similar findings to the recorded histopathological changes were obtained when propineb (Zn-dithiocarbamate) administered orally to female Wistar rats 
Figures (1-9) describing the histopathological changes of liver and kidney in treated rats

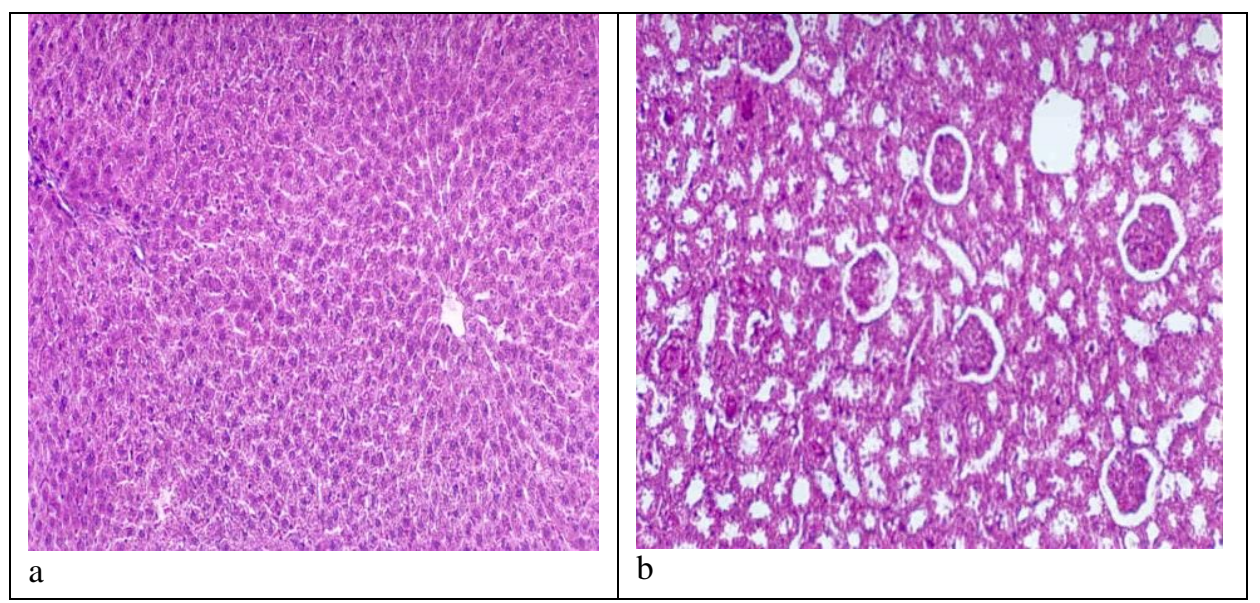

Fig. (1a,b). Section in control liver and kidney of albino rat, showing normal lobular architecture of hepatocytes and renal cells; respectively. (X200)

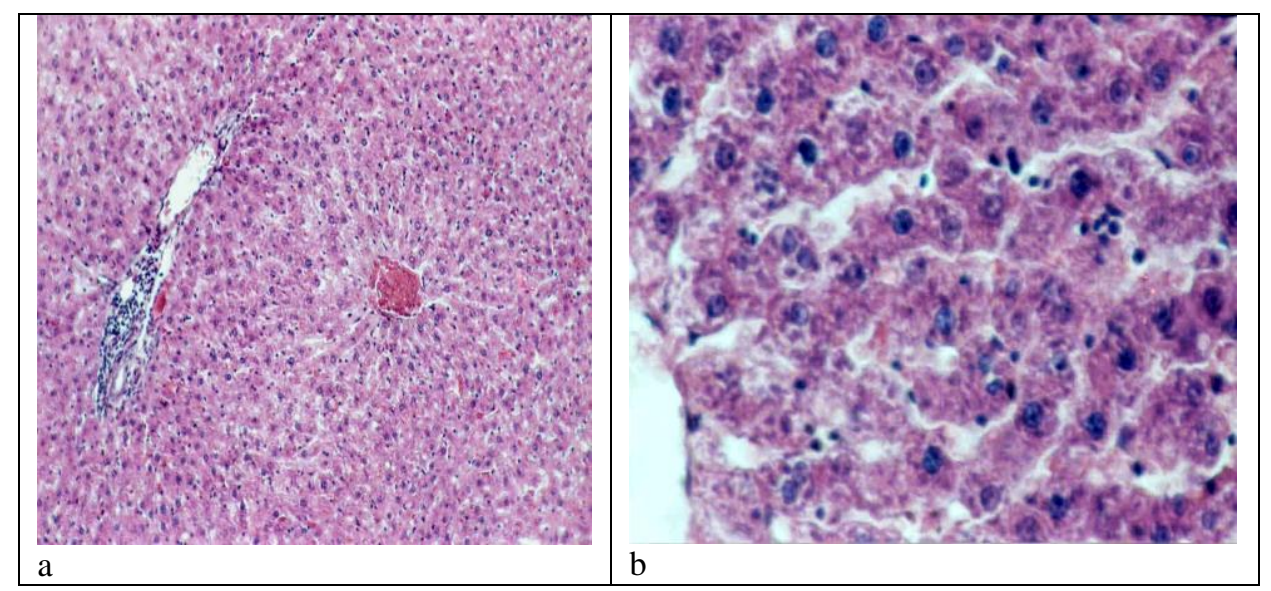

Fig. (2a, b). Histopathological effects of technical mancozeb on liver of rats treated with $500 \mathrm{mg} / \mathrm{Kg}$, showing hyperplasia of Von Kupffer cells, most of hepatocytes appear as coagulative masses of degenerated cytoplasm, dilation and congestion of the portal vein with red blood cells and the sinusoidal spaces engarged with large focal area of mononuclear inflammatory cells (X 200, 400). 


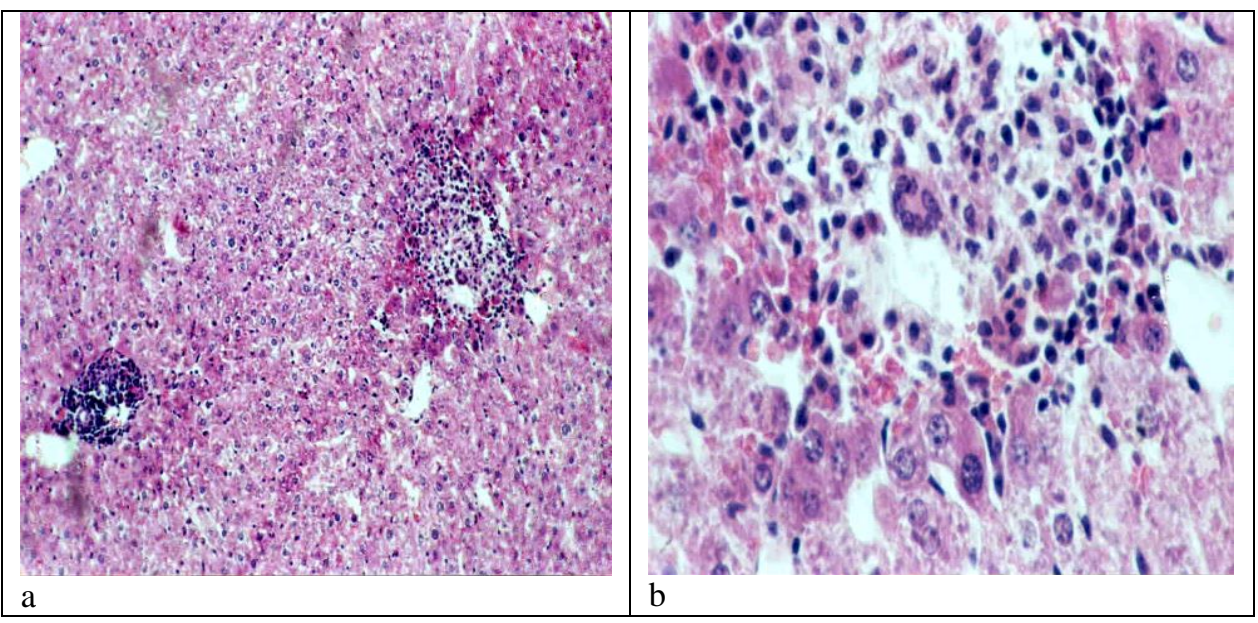

Fig. (3a, b). Photomicrograph of section in liver of rats received $125 \mathrm{mg} / \mathrm{Kg}$ of technical mancozeb showing severe necrosis, hyperplasia of Kupffer cells, congestion of sinusoids between hepatocytes and hemosiderin pigments are seen (X200, 400).

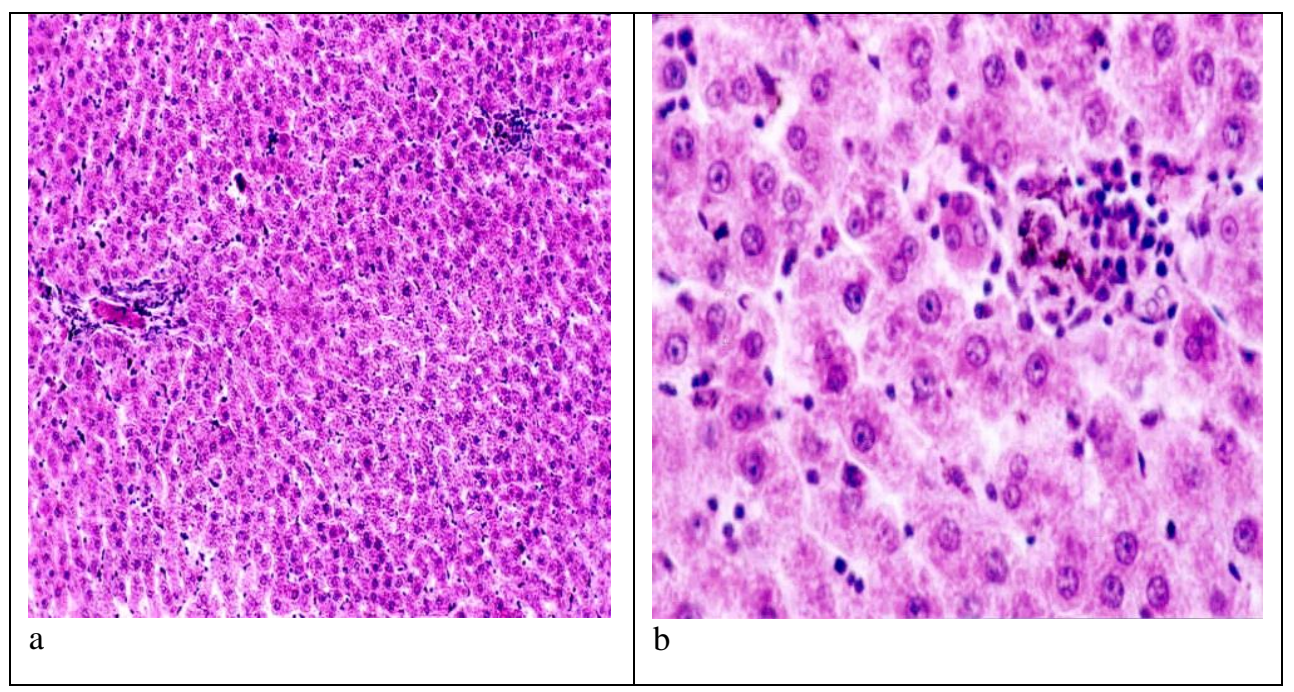

Fig (4a,b). Histopathological effects of formulated mancozeb (Anadol gold) on liver of rats treated with $500 \mathrm{mg} / \mathrm{Kg}$ showing focal areas of inflammatory cells in the whole hepatic lobular architecture, ill-defined cell boundaries, hydropic degeneration of hepatocytes and hemosiderin pigments are highly distributed among Kupffer cells (X200, 400). 

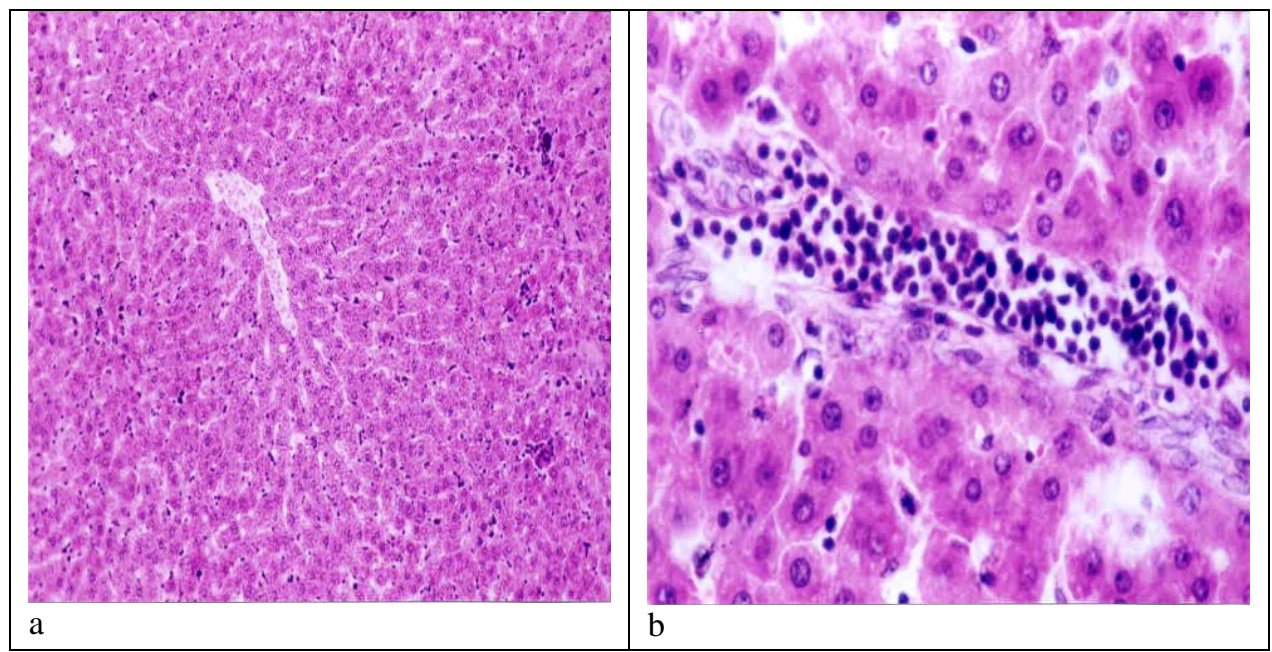

Fig. (5a,b). Histopathological effects of formulated mancozeb (Anadol gold) on liver of rats treated with $125 \mathrm{mg} / \mathrm{Kg}$ showing the same pattern exhibited by the high dose shown in Fig 4, in addition to hydropic and fatty degeneration of lysed hepatocytes, widened and dilated C.V., and absence of the regular arrangement of hepatic strands and architecture (X200, 400).

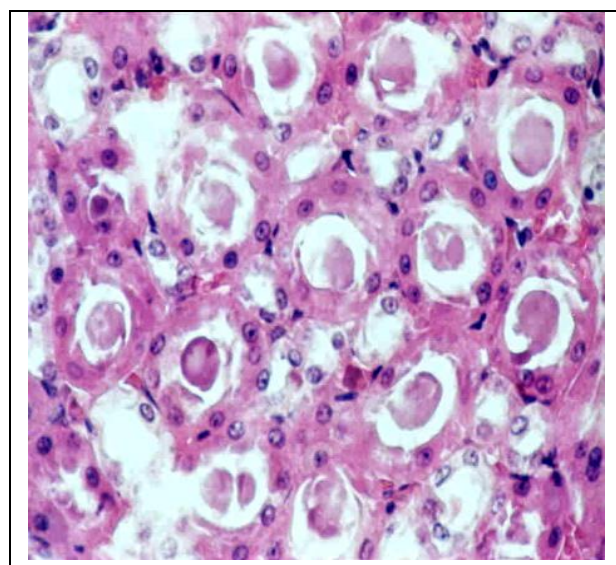

Fig (6)

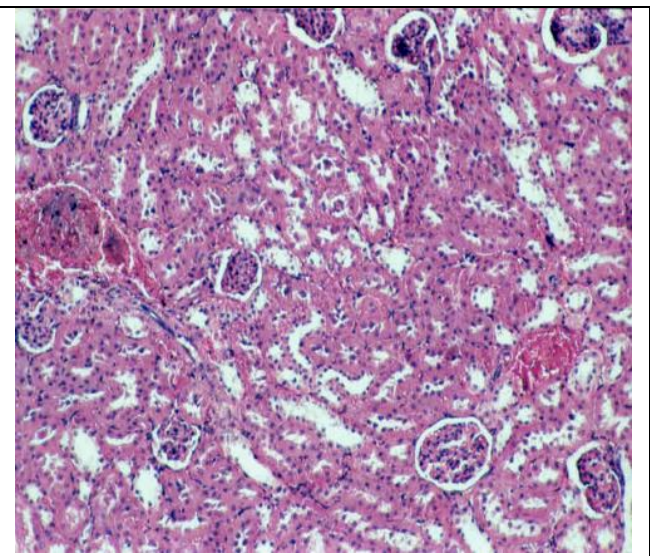

Fig (7)

Fig 6. Histopathological effects of technical Fig 7. Histopathological effects of technical mancozeb on kidney of rats treated with $500 \mathrm{mg} / \mathrm{Kg}$ showing deposition of pink hyaline casts in the renal tubular vacuoles (X200). mancozeb on kidney of rats treated with $125 \mathrm{mg} / \mathrm{Kg}$ showing congested blood vessels between the convoluted tubules (X200). 


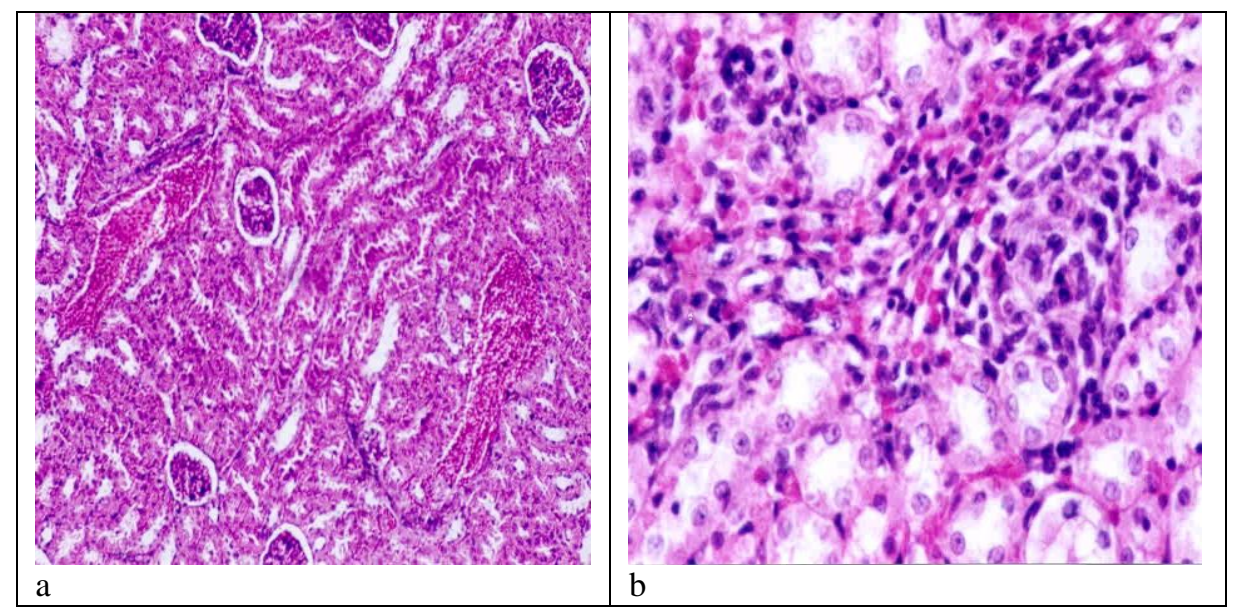

Fig. (8a,b). Histopathological effects of Anadol gold on kidney of rats treated with 500 $\mathrm{mg} / \mathrm{Kg}$ showing focal congestion in glomeruli, interstitial haemorrhage and inflammatory cells between the renal tubules in the corticomedullary junction (X200, 400).

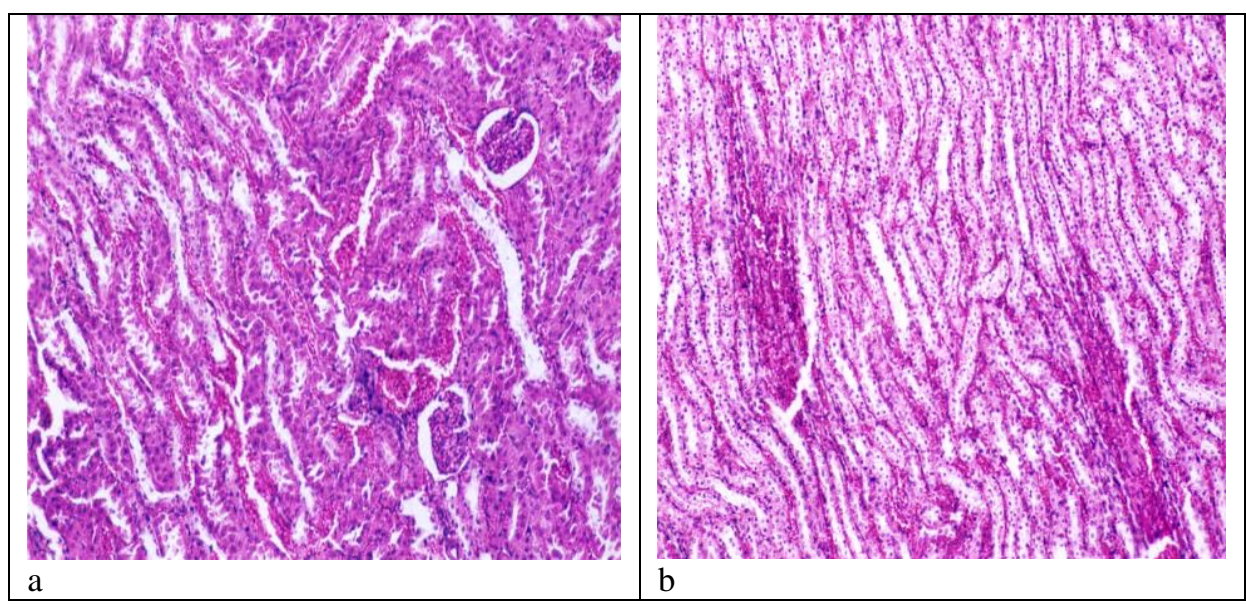

Fig. (9a,b). Histopathological effects of Anadol gold on kidney of rats treated with 125 $\mathrm{mg} / \mathrm{Kg}$ showing the same effect exerted above in addition to dilation, lysis of collecting tubules and marked glomerular degeneration (X200, 400). 
(Guven et al 1999) where histological examination of the liver and kidney of the fetuses and treated pregnant females showed a variety of histopathological changes primarily in the liver and kidney and adenocarcinomas of the uterus.

From the above observations, the histopathological findings confirm the biochemical results and showing that liver and kidney represent sensitive target organs under subchronic mancozeb intoxication. In most cases, the formulated form of mancozeb seems to be more hazardous than the technical one may be due to the synergistic effects of the additives coupled to the technical material. Furthermore, the formulation may carry some unknown impurities that may potentiate the toxic effects of the original compound. Since technical mancozeb is an organometallic compound can enter cells much more readily than the inorganic metal ion (Guven et al 1999), at least part of their toxicity may remit from a rapid rise in intracellular metal concentrations. However, the metabolic fate of this compound (metal release, excretion etc) and the toxicity of the organic moieties also require further study.

\section{REFERENCES}

Abu El-Zahab, H.; W. Abdel Aal; R. Awadallah; T. Mikhail and K. Zakaria (1991). The correlation between serum cholesterol and some trace elements in serum, liver and heart of rats fed with high cholesterol diet. Nahrung, 35: 827834.

Atamanalp, M. and T. Yanik (2003). Alterations in hematological parameters of rainbow trout (Oncorhynchus mykiss) exposed to mancozeb. Turk. J. Vet. Anim. Sci., 27: 1213-1217.
Baligar, P. and B. Kaliwal (2001). Induction of gonadal toxicity to female rats after chronic exposure to mancozeb. Ind. J. Health, 39(3): 235-243.

Belpoggi, F.; M. Soffritti; M. Guarino; L. Lambertini; D. Cevolani and C. Maltoni (2002). Results of long-term experimental studies on the carcinogenicity of ethylene-bis-dithiocarbamet (Mancozeb) in rats. Ann. NY. Acad. Sci., 982: 123-136.

Carleton, H.; R. Druy; E. Willingaton and S. Coneron (1967). Histological Techniques, $4^{\text {th }}$ Ed., pp. 125-137. Oxford Univ Press, N.Y., USA.

Dacosto, M.; O. Abate and C. Nebbia (1994). Subacute toxicity of triphenyltin acetate (TPTA) in the rabbit. Clinical observations and hematologic, hematochemical and enzymatic changes. Schweiz Arch. Tiechnol., 136(3): 111115.

El-Halwagy, M.; G. Abd El-Raheim and M. Rizk Alla (2003). Subacute effect of sulfur containing fungicide on some hematological and biochemical changes in rat. Egypt J. Appl. Sci., 18(8B): 681-694.

Goyer, R. (1986). Toxic effects of metals. In: Casarett and Doul's Toxicology, The Basic Science of Poisons, edited by Mary Amdur, O. John Doull and Curtis D. Klaassen), pp. 623-680. Pergamon Press, N.Y., USA.

Guven, K.; E. Deveci and D. de Pomerai (1999). The accumulation and histological effects of the organometallic fungicide Propineb on the organs of the fetuses and female rats during pregnancy. Tr. J. Biol., 22: 413-422.

Hasegawa, R.; R. Cabral; T. Hoshiya; K. Hakoi; T. Ogiso; P. Bonyaphiphat; T. Shirai and N. Ito (1993). Carcinogenic potential of some pesticides in a medi- 
um-term multi-organ bioassay in rats. Int. J. Cancer, 54: 489-493.

Hashizame, K.; T. Yasui and H. Nagano (1992). Studies on the fate of thiabendazol in mice. Japanese J. Toxicol. Environ. Health, 38(1): 69-77.

Hassal, K. (1990). The Biochemistry and Use of Pesticides: Structure, metabolism, mode of action and uses in crop protection. pp. 263-361, VCH Publishers Inc., N.Y., USA.

Jeffrey, M.; L. Charles; A. Tobia and B. Ravenz Waay (2000). Subchronic and chronic toxicological investigations on metiram: The lack of a carcinogenic response in rodents. Toxicol. Sci., 54: 481492.

Kackar, R.; M. Srivastava and R. Raizada (1997). Induction of gonadal toxicity to male rats after chronic exposure to mancozeb. Ind. Health, 35(1): 104-111.

Kackar, R.; M. Srivastava and R. Raizada (1999). Assessment of toxicological effects of mancozeb in male rats after chronic exposure. Ind. J. Exp. Biol., 37(6): 553-559.

Kelly, W. (1993). The liver and biliary system. In: Pathology of Domestic Animals, Jubb, K.V. and N., Plameer (eds.). Vol. 2, $4^{\text {th }}$ Ed., pp. 319-406. Academic press, London.

Kendrick, M.; M. May; M. Plishka and K. Robinson (1992). Metals in Biological Systems. p. 179. E. Horwood, N.Y., USA.

Larsson, K.; C. Arnander; E. Cekanova and M. Kjellberg (1976). Studies of teratogenic effects of the dithiocarbamates maneb, mancozeb and propineb. Teratology, 14: 171-184.

Lukens, R. (1971). Chemistry of Fungicidal Action. p. 125. Springer-Verlag, N.Y., USA.
Mahadevaswami, M.; U. Jadaram Kunti; M. Hiremath and B. Kaliwal (2000). Effect of mancozeb on ovarian compensatory hypertrophy and biochemical constituents in hemicastrated albino rat. Reprod. Toxicol., 14(2): 127-134.

-Meco, G.; V. Bonifati; N. Vanacore and E. Fabrizio (1994). Parkinsonism after chronic exposure to the fungicide maneb (manganese ethylene-bisdithiocarbamate). Scand. J. Work. Environ. Health, 20: 301-305.

Organization for Economic Cooperation and Development (OECD): Guidelines for Testing Chemicals, 406 (Adopted in 1995)

Prasadad, A. (1979). Clinical, biochemical and pharmacological role of zinc. Ann. Rev. Pharmacol. Toxicol., 20: 393426.

Rizk Alla, M.; S. Abo-Seada and M. Talha (2004). Biochemical effects of crunch on male albino rats. Egypt $\boldsymbol{J}$. Appl. Sci., 19(1): 212-223.

Schalm, O. (1986). Veterinary Hematology. $4^{\text {th }}$ Ed., pp. 21-36. Lea and Febiger, Philadelphia, USA.

Snedecor, G.W. and W.G. Cochran. (1989). Statistical Methods. $\mathbf{8}^{\text {th }}$ Ed., 503pp. Ames, Iowa State Univ Press, USA.

Siddiqui, A.; S. Srivastava and B. Ali (1990). Effect of mancozeb on hydrolytic metabolism of xenobiotics. Res. Commun. Chem. Pathol. Pharmacol., 70(2): 249-252.

Soleo, L.; G. Defazio; R. Scarcelli; R. Zefferino; P. Livrea and V. Foa (1996). Toxicity of fungicides containing ethylene-bis-dithiocarbamate in serumless dissociated mesencephalic-striatal primary coculture. Arch. Toxicol., 70: 678682. 
Subramoniam, A.; D. Agrawal; S. Srivastava and $P$. Seth (1991). Influence of mancozeb on mitogenically responsive lipids in rat cerebrum and liver. Ind. $\boldsymbol{J}$. Exp. Biol., 29: 943-5.

Szepvolgyi, J.; K. Nagy; K. Sajgone Vukan; A. Regoly Merel; K. Soos; K. Toth; A. Pinter and M. Antal (1989). Subacute toxicological examination of Dithane M-45. Food Chem. Toxicol., 27(8): 531-538.

Terada, M.; F. Mizuhashi; T. Tanita; H. Inueand and K. Murata (1998). Mepanipyrn induces fatty liver in rats but not in mice and dogs. J. Toxicol. Sci., 23(3): 223-234.

Teramoto, S.; M. Kaneda and Y. Shirasu (1975). Teratogenicity of ethylenethiourea in rats. Relationship of dosage and time of administration to types of malformation. Teratology, pp. 215-216.
Timbrell, J. (1991). Principles of Biochemical Toxicology. p. 415. Taylor and Francis, London.

Trivedi, N.; R. Kakkar; M. Srivastava; A. Mithal and R. Raizada (1993). Effect of oral administration of fungicidemancozeb on thyroid gland of rat. Ind. $J$. Exp. Biol., 31: 564-566.

Verplanke, A.; L. Bloemen; E. Brouwer; N. Van Sittert and $P$. Boogaard (2000). Occupational exposure to cis-1,3-dichloropronene: biochemical effect monitoring of kidney and liver function. Occup. Environ. Med., 57: 745-751.

Ware, G. (1983). Pesticides: Theory and Application. p. 293. W.H. Freeman and Company, N.Y., USA.

Wlostowski, T. (1992). On metallothionein, cadmium, copper and zinc relationships in the liver and kidney of adult rats. Comp. Biochem. Physiol., 103C: 35-41. 
بحلة اتحاد الجامعات العربية للدراسات والبحوث الزراعية ، جامعة عين شمس ، القاهرة ،14(1) ، 457-474 ، 2006

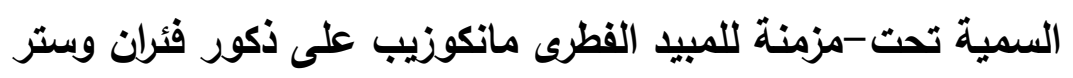
التحليل البنائى الاقيق لأنسجة الكبا و الكلى ملئ

[31]

$$
\text { مديحة طلحة - عنتر قناوى1 - سلوى عبد الله1 }
$$

1- قسم سمية المبيدات للثييات - المعمل المركزى للمبيدات - مركز البحوث الزراعية - الإسكندرية علدية

فى نمط يعتمد على الجرعة و زمن المعاملة

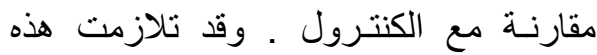

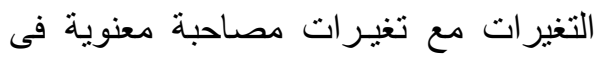
دلائل أخرى مثل كمية البروتين الكلى فئل والزلال و الجلوكوز والدهون الكلية وتثلاثى الجئي

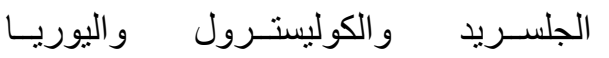
و الكرياتينين.

وفضلا عن ذلك فقد أظهر فحص أنسجة

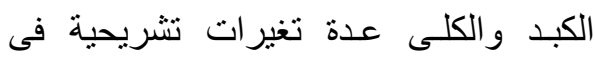

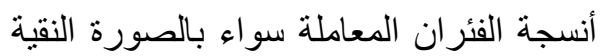
أو المجهزة للمركب.

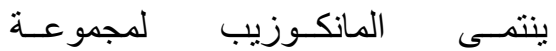
دايثيوكرباميت ويعد مبيد فطرى معدنىعضوى وقد أعطى عن طريق الفم لذكور

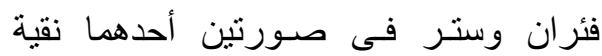

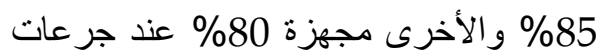
تحت مميتة وهى مجم/كجم من وزن الجسم و لمدة 28 يوم.

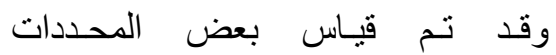

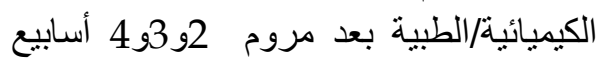

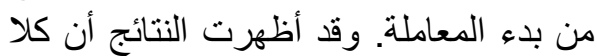

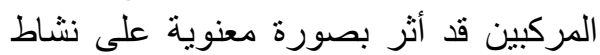
أنزيمات السيرم وخاصة أنزيمات الكبد وذلكي

تحكيم: أ.د زيدان هندى عبد الحميد أ.بد مصطفى عبد السميع الهراوى ليدى 